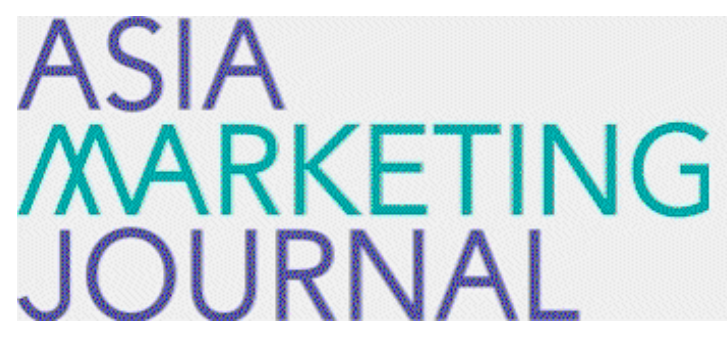

ASIA MARKETING JOURNAL

Volume 20 | Issue 3

Article 4

10-31-2018

\title{
The Dark Side of Star Marketing
}

Hojoon Jang

Kyoungmi Lee

Follow this and additional works at: https://amj.kma.re.kr/journal

Part of the Marketing Commons

\section{Recommended Citation}

Jang, Hojoon and Lee, Kyoungmi (2018) "The Dark Side of Star Marketing," Asia Marketing Journal: Vol. 20 : Iss. 3 , Article 4.

Available at: https://doi.org/10.15830/amj.2018.20.3.63

This Article is brought to you for free and open access by Asia Marketing Journal. It has been accepted for inclusion in Asia Marketing Journal by an authorized editor of Asia Marketing Journal. 


\title{
The Dark Side of Star Marketing: Celebrity Endorsement Contracts Can Lower Consumers' Judgment of Brand Growth When the Firm is Tech-Focused*
}

\author{
Hojoon Jang** \\ Kyoungmi Lee L*** $^{*}$
}

\begin{abstract}
This research examines how the announcement of a celebrity endorsement contract with a brand can influence consumers' judgment of its future growth in a market. Using both behavioral experiments and an event study analysis, we find that when the brand is perceived to be technology-focused (versus marketing-focused), the information about the celebrity contract can lead consumers to view the brand's future as less promising. Furthermore, we identify consumers' inferences about the quality of the brand as a psychological factor underlying this effect. This paper provides evidence that star-marketing can sometimes signal management's misjudgment about resource allocation for a brand, which unduly invests in celebrity marketing at the expense of quality improvement for the product.
\end{abstract}

Key words: celebrity marketing, strategic focus, consumer inference, brand growth judgment, categorization

Recently, it is increasingly hard for marketers to resist the temptations of celebrity endorsements for their products, so-called star marketing, because simple exposure of celebrity influencers seems to attract consumers' attention significantly and build favorable attitudes toward a brand (Mowen and Brown 1981; Paek 2005). Moreover, such propensity is expected to increase as millennial generations, known to be strongly influenced by celebrities in social media, become

This work was supported by the SNU Institute of Management Research

** Graduate Student, College of Business Administration, Seoul National University (hjang0527@snu.ac.kr)

*** Associate Professor, College of Business Administration, Seoul National University (kyoungmi@snu.ac.kr),

Corresponding Author 
major consumers (Gullov-Singh 2011).

Then, what do consumers infer about a firm's investment in celebrity marketing concerning its impact on the brand's growth in a market? The vast majority of marketing research in the effects of a celebrity endorsement has focused on advertising effectiveness such as consumer memory and attitude toward an ad and a brand. For example, a celebrity endorsement tends to enhance consumer attitudes toward the product, the retrieval of the advertisement, and the credibility of the advertisement (Friedman and Friedman 1979; Heath, McCarthy, and Mothersbaugh 1994; Kamins et al. 1989; McCracken 1989).

However, relatively little is understood regarding how consumers make inferences about a brand's growth in the market in response to its marketing actions involving a celebrity endorsement contract. That is, would information lead consumers to believe that the brand will thrive in the future, since a celebrity endorsement can increase consumers' attention to the brand? Or, would consumers instead be led to believe that the brand may not perform well in the future, because it does not sufficiently allocate its resource for quality improvement?

In this research, we propose that the perceived strategic focus of a brand can moderate the effect of celebrity endorsement contracts on consumers' judgments about the brand's growth. Specifically, this research suggests that when a company is described as technology-focused versus marketing-focused, consumers will infer that the firm sacrifices the resource that should be allocated to enhancing product quality, leading to the belief that the brand may not be successful in the future.

\section{Theoretical Background}

\subsection{Celebrity Contract and Consumer Inference about a Brand}

In this paper, we propose that a celebrity contract with a brand may serve as a cue for inferential bases to make a judgment about the brand. Ample research has shown that a variety of factors regarding a brand's marketing actions such as advertising efforts and contents operate as a cue for consumer inferences and subsequent judgments of the brand. For example, consumers tend to infer the high level of product quality when a company engages in substantial advertising, because they believe that the firm must be confident in its product (Kirmani and Wright 1989). When the information about a firm's profitability is featured in an advertisement, consumers tend to infer that a company has positive characteristics and subsequently form a favorable evaluation about the advertisement and the product offered by the company (Posavac et al. 2010). Also, from the comparative advertisement that praises a 
target brand yet criticize its competitor, consumers tend to infer the brand's motives unfavorably (Jain and Posavac 2004).

However, little is known about what consumers infer from the information about a brand's contract with a celebrity or star marketing. Since celebrity marketing is generally considered to have substantial investment in marketing (Agrawal and Kamakura 1995), it is likely that consumers may perceive the celebrity marketing as a cue for a company's resource allocation. Supporting this notion, past research in strategy and management literature suggested that information on the market action of firms such as marketing expenditures and advertising contracts can signal the firm's current resource levels (Rindova, Pollock, and Hayward 2006; Weigelt and Cemerer 1988). Similarly, Newman, Gorlin, and Dhar (2014) found that when a company is communicated as intentionally producing an environmentally-friendly product, consumers infer that the company devoted resources to producing green products. That is, consumers may interpret the description about a company's marketing efforts in one area as reference to the firm's current resource allocations. In this respect, when the information of a celebrity contract with a brand is present, consumers may infer that the brand spends greater resources of a company in marketing than other areas.

\subsection{The Moderating Role of Strategic Focus on Consumer Judgment}

As noted earlier, we propose that consumers may infer a brand's resource allocation from a celebrity endorsement contract with the brand. Then, what types of subsequent brand evaluation would be made from the inference? In this paper, we focus on consumers' judgment on whether the brand would continue to grow in the marketplace, that is, a brand's future growth perception.

We argue that consumers' judgment about a brand's future growth would depend on how the company is categorized in a consumer's mind. A category is a set of objects that appear to be related and grouped together in some way (Rosch 1978). In consumer research, categories include "groups of product, services, brands or other marketing entities, states or events that appear, to the consumer, related in some way" (Loken, Barsalou, and Joiner 2008, p. 133). A line of research has demonstrated that categories that consumers have in their minds help them to form inferences and evaluations about products, brands, and companies (Gershoff and Frels 2015: Gregan-Paxton, Hoeffler, and Zhao 2005; Loken, Barsalou and Joiner 2008). Therefore, we contribute to this line of research by examining an additional aspect of categorization that consumers have, which is the strategic focus of a company.

Strategic focus refers to the strategical 
commitment of a firm in order to realize the full competitive potential (Grant 1999). Previous research has often categorized the strategic focus of firms as technology-focused versus marketing-focused (Gatignon and Xuereb 1997; Zhou, Yim, and Tse 2005). Technology-focused firms are characterized as concentrating their resources on new product development and innovative technology (Zhou, Yim, and Tse 2005). On the other hand, marketing-focused firms are characterized as concentrating their resources on building consumers' trust, loyalty, and overall brand image.

Previous research suggested that consumers tend to believe that a company's marketing action in one area is compensated at the expense of its resource allocation in a different area (Newman, Gorlin, and Dhar 2014). For example, Newman, Gorlin, and Dhar (2014) suggested that consumers believe that a company diverts resources away from product quality to its intentional marketing efforts such as communicating its focus on environmental friendliness. Similarly, Chernev and Carpenter (2001) suggested that consumers have a lay theory that firm's resources are zero-sum; thus, superiority on a product attribute is compensated by inferiority on another attribute ("compensatory inference strategy"). They further suggested that this consumer inference is moderated by consumers' understanding of competitiveness in the market - that is, categorization of a market as either efficient or inefficient. In other words, when consumers have the lay theory about a competitive nature of a market (versus not), they infer that superior attributes on one dimension are possible at the expense of other attributes on the other dimension. This research indicates that consumers may believe that companies can have a finite resource in a competitive market. Thus, investment in one area can be managed by diverting resources away from the other area.

In this respect, consumers may come to a negative inferential conclusion based on a celebrity contract with a brand when they categorize the firm as technology-driven. They may regard the celebrity contract as less focused actions of a firm that take away resources from the deserving areas such as R \& D investment and product advancement. Accordingly, consumers may develop negative judgments of a product quality. Since the quality of a product is an essential predictor of brand growth (Aaker 1989; Babakus, Bienstock, and Van Scotter 2004; Jacobson and Aaker 1987), we predict that this negative evaluation of product quality may lead to form a belief that the brand compromises its future growth. On the other hand, consumers' inferential conclusion from a celebrity contract may not be so negative when they categorize the firm as marketingdriven. This is because a celebrity contract for a brand may be considered as a legitimate investment aligned well with its strategic focus, that is, nurturing brand image (Keller 1992; 
Park, Jaworski, and Maclnnis 1986). Thus, a celebrity endorsement contract with a brand may not hurt consumers judgment about the brand's future growth. This notion is supported by previous research suggesting that consumers' inferential conclusions from a cue depend on what kinds of beliefs that consumers hold at the time of information receipt (Schwarz 2004). That is, the same marketing action can be judged as legitimate or not, depending on a firm's strategic focus that can justify the resource allocation in marketing. As a result, the subsequent consumer judgment such as a brand's growth in the future may diverge. Therefore, we propose the following two hypotheses:

H1: In response to a celebrity endorsement contract, when a firm is described as technology-oriented versus marketingoriented, consumers are more likely to make a lower evaluation about the brand's future growth.

H2: The effect of a celebrity endorsement on the brand's growth judgment is mediated by consumers inferring lower product quality when the firm is described as technology-oriented.

We propose that a celebrity endorsement contract may induce consumers' inference of lower quality of the product when the firm is seen as technology-focused versus marketing- focused. Consequently, this perception of lower quality may lead consumers to expect the lower growth of the brand in a market.

\section{Overview of the Research}

The present research examined through three studies whether a celebrity endorsement contract can negatively affect consumers' perceptions of a brand regarding its growth in a market when a firm is categorized as technologyfocused versus marketing-focused. In Study 1 , we sought to test our key notion of the backfiring effect of a celebrity endorsement contract for technology-focused firms by using a behavioral experiment. In Study 2, we examined the role of quality inference toward the endorsed products in linking the effect of a celebrity endorsement contract on the perceived brand growth of the technology-focused firm. In Study 3, we conducted an event study by adapting the methodological procedure of Agrawal and Kamakura (1995). By analyzing the cumulative average abnormal return (CAAR) of the two types of firms, we examined whether the announcement of a celebrity endorsement contract would give a negative impact on the future profitability of the technology-focused firms, rather than the marketing-focused firms. 


\section{Study 1}

In Study 1, we examined whether information on a celebrity endorsement contract would negatively affect consumers' judgment about the brand growth when the brand is categorized as technology-focused versus marketing-focused brand.

\subsection{Method}

178 participants (77 women, $M_{\text {age }}=32.65$ ) were recruited using Amazon Mechanical Turk (M-Turk) in exchange for nominal monetary compensation. The study employed 2 (strategic focus: technology-focused vs. marketing-focused) $\times 2$ (information on a celebrity endorsement contract: presence vs. absence) between-subjects design. The participants were randomly assigned to one of the four conditions.

\subsubsection{Strategic focus manipulation}

In the technology-focused condition, participants were presented with a brand named as "Joyler Tech \& Software" reflecting a high-tech based strategic focus. Specifically, the brand was described as "a high-technology brand that embodies a human-computer interaction system," "invests highly in technology R\&D," and focuses on "creating consumer products that are scientifically designed such as biomechanical engineering technology." Participants in the marketing-focused condition were presented with the brand named "Joyler Fashion \& Beauty." Specifically, the brand was described as "a clothing brand that embodies the latest style," "invests highly in its marketing strategy," and focuses on "creating consumer products that are fashionable including high-quality design.”

\subsubsection{Manipulation of information on a celebrity endorsement contract}

Participants in the celebrity condition (i.e., an announcement of a celebrity endorsement contract is present) were presented with a news article indicating that the brand signed an endorsement contract with a world-widely popular movie star. The content of the news articles was identical, except the name of the brand was provided depending on the strategic focus of the firm as noted earlier. Participants in the non-celebrity condition were not given any news article.

\subsection{Procedure}

First, participants in each strategic focus condition read the brand description. Second, participants in the celebrity condition were informed about the announcement of a celebrity endorsement contract whereas those in the non-celebrity condition were not informed. Third, the participants were asked to indicate their 
opinions about the brand's growth with three items, (bad/good, negative/positive, poor/ superior; $\alpha=.88$ ) using a 100-point slider scale. Finally, the participants answered several demographic questions and were debriefed and thanked.

\subsection{Results}

\subsubsection{Perceived brand growth}

A 2 (strategic focus) $\times 2$ (celebrity endorsement) analysis of variance on perceived brand growth revealed a significant two-way interaction $\left(F(1,174)=6.19, p<.05, \eta_{p}^{2}=.03\right.$; Figure 1). No other effects were significant ( $p$ s $>.64$ ). The planned contrasts analyses revealed that, as predicted, when the firm was described as technology-focused, participants expected the brand's growth to be lower in the celebrity condition versus the non-celebrity condition $\left(M_{\mathrm{yes}}=63.58, S D=19.17\right.$ vs. $M_{\mathrm{no}}=71.75$, $S D=18.69 ; t(174)=-2.04, p=.04)$. In contrast, when the firm was described as marketing-focused, consumers' judgments about the brand's growth did not differ as a function of a celebrity endorsement contract announcement $\left(M_{\text {yes }}=75.33, S D=19.65\right.$ vs. $M_{\text {no }}=69.63$, $S D=16.84 ; t(174)=1.47, \mathrm{NS})$.

\subsection{Discussion}

In Study 1, we found that when a firm was described as technology-focused, participants expected the lower growth of the brand in the presence of information about a celebrity

〈Figure 1〉 The Effect of Strategic Focus and a Celebrity Endorsement Contract Announcement on Perceived Brand Growth (Note: Error bars based on 95\% confidence intervals)

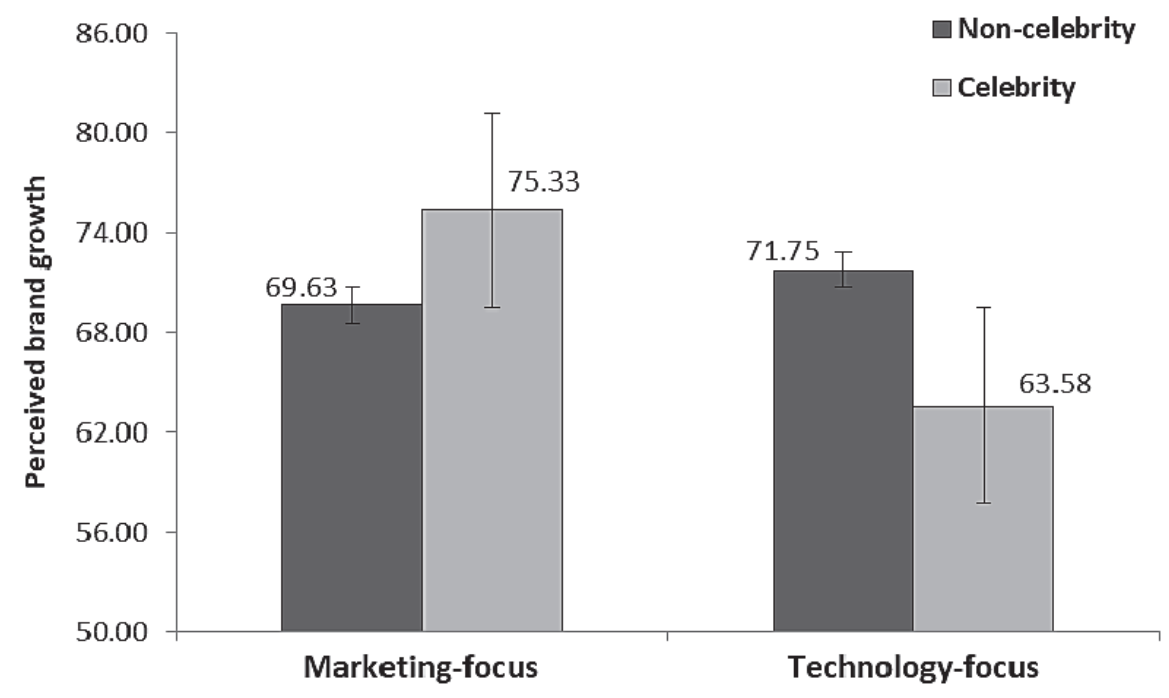


endorsement contract versus not having a contract. However, when a firm was described as marketing-focus, the brand growth judgment was not affected by the presence of celebrity endorsement contract information. In Study 2, we examined the mechanism underlying the effect of consumer inference about a celebrity endorsement contract on a brand's future growth judgment.

\section{Study 2}

This study sought to examine the underlying mechanism that can explain the effect of a celebrity endorsement contract on the perceived brand growth of the technology-focused firm. We predicted that the quality perception of a brand can mediate the effect of a celebrity endorsement contract on consumer's judgment about a brand's future growth.

\subsection{Method}

167 participants (63 women, $M_{\text {age }}=32.73$ ) were recruited from M-Turk for nominal monetary compensation. The study employed a single factor (information on a celebrity endorsement contract: presence vs. absence) between-subjects design. Participants were randomly assigned to one of the two celebrity conditions. That is, all of the participants were presented with a description page of a watch brand that is intended to be technology-focused. We used the same stimuli about celebrity endorsement contract and the technology-focused.

In terms of measures, we assessed opinions about the brand's growth in terms of firm value with a single item (bad/good) on a 7-point Likert scale. Also, we measured our proposed mediator, the quality inference related to the brand products, by asking participants how they feel about the brand's products with five items (low quality/high quality, not helpful /helpful, not functional/functional, not necessary /necessary, impractical/practical; adapted from Voss, Spangernberg, and Grohmann 2003) on a 7-point Likert scale $(\alpha=.87)$.

\subsection{Results}

\subsubsection{Perceived brand growth}

A one-factor (celebrity contract information: presence vs. absence) analysis of variance (ANOVA) on the perceived growth of the brand revealed that there was a significant difference between the celebrity and noncelebrity conditions on the perceived brand growth $(F(1,165)=3.08, p<.05$, one-tailed, $\left.\eta_{p}^{2}=.02\right)$. The participants who were informed about the celebrity contract perceived lower brand growth $\left(M_{\text {celeb }}=5.25, S D=1.16\right)$ than those who were not informed about the contract $\left(M_{\text {non-celeb }}=5.57, S D=1.24\right)$. This supports 
our hypothesis that the celebrity endorsement contract announcement from the technologyfocused brand can decrease the brand's growth which the individuals perceived.

\subsubsection{Perceived product quality}

As predicted, a one-factor (celebrity: yes vs. no) ANOVA on perceived product quality revealed that participants in the celebrity condition inferred lower product quality than the participants in the non-celebrity condition $\left(F(1,165)=5.70, p<.05\right.$, one-tailed, $\eta_{p}^{2}=$ .03). Specifically, participants in the celebrity condition $\left(M_{\text {celeb }}=4.89, S D=1.09\right)$ perceived lower product quality than those in the noncelebrity condition $\left(M_{\text {non-celeb }}=5.30, S D=\right.$ 1.13). Thus, consistent with our hypothesis, the information on the celebrity endorsement contract reduced participants' inferred product quality of the technology-focus brand.

\subsubsection{Mediation analysis}

We tested the proposed mediating role of the product quality perception in the relationship between the celebrity endorsement contract and a brand's growth perception. The bootstrapping procedure (PROCESS model 4; Hayes 2017; Preacher and Hayes 2008) was used with 5,000 samples. As a result, consistent with the hypothesis, we found that the effect of the celebrity endorsement on consumers' perceived brand growth was mediated by the quality inference $($ point estimate $=-.32,95 \% \mathrm{CI}=$ [-.60, -.06]; Figure 2).

\subsection{Discussion}

In Study 2, we found that the celebrity endorsement contract announcement from a technology-focused brand negatively affected consumers' perception of the brand's growth

〈Figure 2〉 The Effect of a Celebrity Endorsement Contract Announcement on Perceived Brand Growth mediated by quality inference

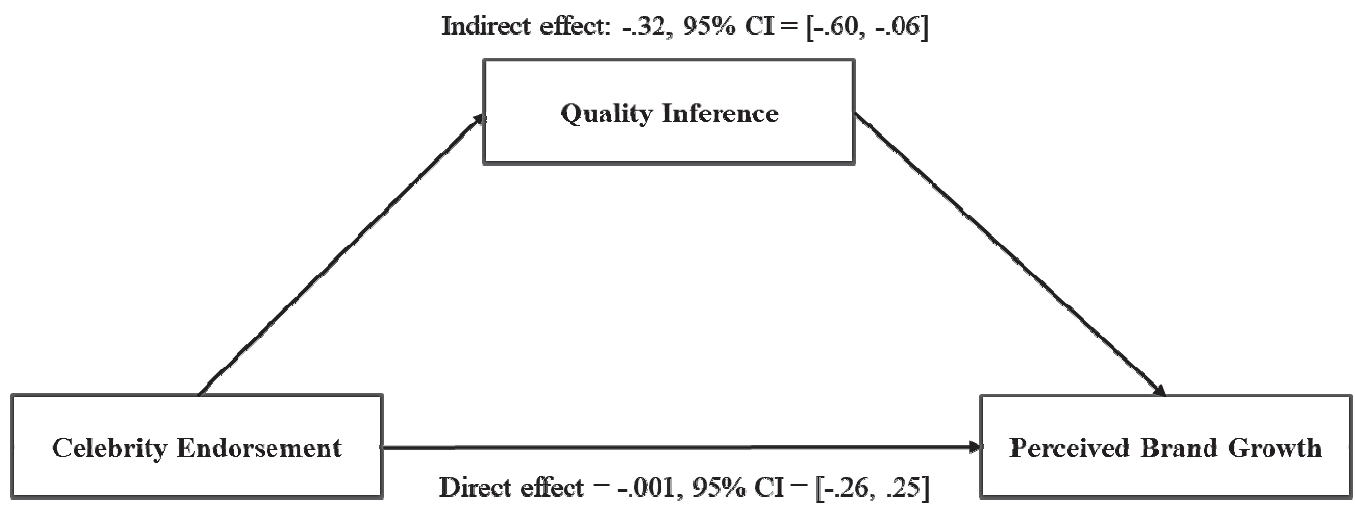


because of negative product quality inferences. We also replicated the effect of the celebrity endorsement contract on perceived brand growth, which was observed consistently in Study 1 and Study 2. These findings provide converging evidence for the notion that when a brand is categorized as technology-focused, the celebrity endorsement contract can negatively serve a cue for consumers to infer the firm's less desirable investment of its resources, thereby leading to lower brand quality perception and brand growth in the future marketplace.

\section{Study 3}

In Study 1 and Study 2, we used experiments to identify the proposed effect of the celebrity endorsement contract in consumers' judgments about a brand's growth. In Study 3, we sought to provide empirical evidence for the proposed effect using a multi-method approach using an event study. Previous literature has shown that stock prices are reliable indicators of the firm's growth including future profitability and expected return (Agrawal and Kamakura 1995; Fama et al. 1969). If a celebrity endorsement announcement is assumed to influence the company's potential profits, the stock price will be affected as the market becomes aware of the information, because the estimated economic value of the event will reflect such change in the stock price (Brown and Warner 1985).

Accordingly, we used the market model to obtain the abnormal return (AR) for the South Korea stock market, and to observe the impact of a contract announcement on the firm value. The excess return indicates the change in stock price and is adjusted for the economic state of the market (Agrawal and Kamakura 1995). We predicted that the celebrity endorsement contract would reduce future profitability of technology-focused firms but not that of marketing-focused firms. To test this prediction, we conduct an event study to measure the cumulative average abnormal returns (CAAR) of the two categories of firms.

\subsection{Sample Selection}

The samples for the present study were selected based on the industry classification of the Korean Standard Industry Classification (KSIC) and WISEfn Sector Classification (WICS) index among the companies listed on the KOSPI (Korea Composite Stock Prices Index) and the KOSDAQ (Korean Securities Dealers Automated Quotations) from 2014 to 2016. Previous research classified industry standards from the perspectives of markets and products by utilizing firm-centric survey data as shown in Table 1. This classification was considered as more suitable indicators than looking at the amount of R\&D investment or patent output in terms of classifying the industry standards 
〈Table 1〉 Modified Categories of Korea Standard Industrial Classification (KSIC) according to the Level of Technological Intensity (Oh, Cho, and Kim 2015)

\begin{tabular}{cl}
\hline Category & \multicolumn{1}{c}{ KSIC industry } \\
\hline High tech & Medical engineering, computer, electronics, aerospace, engineering, nuclear engineering \\
Low tech & $\begin{array}{l}\text { Food products, fabric products, apparels, leather products, leather bags, shoes, lumber } \\
\text { and wooden products, pulp and paper products, publication and printing, recording } \\
\text { media, duplication, furniture }\end{array}$ \\
\hline
\end{tabular}

(Oh, Cho, and Kim 2015). Adapting both the modified KSIC according to the level of technological intensity (Table 1) and our notion of strategic focus, we categorized firms into two types for the data analysis. Technologyfocused companies included computer, electronics, software development, satellite communication, aerospace engineering, and automobile firms. Marketing-focused companies included food, fabric, apparels, shoes, cosmetics, pulp and paper, and furniture firms.

\subsection{Data Collection}

In the present study, the event day is defined as the date of the announcement of a celebrity endorsement contract between a company and a celebrity, or the date when a contract announcement first appeared on the media. Based on prior literature, a celebrity is defined as the individual who enjoys public recognition and who are responsible for the evaluating products on behalf of consumers through advertising (McCracken 1989). Therefore, all of the announcements of celebrity contracts from January 1, 2014 to December 31, 2016 were explored using the Korean Integrated News Database System (KINDS) keyword search and various news services.

As a result, we found that 37 of 643 technologyfocused firms had an announced celebrity endorsement contract, and 89 events were observed. We also found that 38 of 140 marketing-focused firms had announced the contract, and 141 events were exposed to media (Table 2). Specifically, $5.75 \%$ of the technologyfocused firms and $27.14 \%$ of the marketingfocused firms had announced the celebrity endorsement contract. We used time series data provided by FnGuide to collect the stock data of each firm. During this process, we excluded events with the following cases: (1) if the stock data of the celebrity endorsing company is not available for more than 200 days starting from two weeks before the event; (2) if a major event other than a celebrity endorsement contract occurs within the event window (e.g., stock split, legislative act, regulatory ruling); (3) if a firm is classified as a financial institution (a financial firm's high leverage does not have the same meaning as non-financial firms, Fama and French 1992). 
〈Table 2〉 Types of Firms and Firms with a Celebrity Endorsement Contract Announcement

\begin{tabular}{cl}
\hline Firm types & \multicolumn{1}{c}{ Firms associated with celebrity endorsement announcements } \\
\hline & Samsung Electronics, LG Electronics, Cuckoo Electronics, Kyung Dong Navien, \\
& Winix Inc., Dayou Winia Co., Cuchen, ZAIGLE Co., Paseko, Samjin Inc., \\
& Hyundai Motors, Kia Motors, SK Telecom, Neowiz Games, Thinkware, \\
& HanbitSoft, LG Uplus, Nexon Co., Mgame, WeMade Entertainment Co., Webjen, \\
& Com2uS, Gamevil Inc., NHN Entertainment Corp, PATIGAMES, NCSOFT, \\
& Joycity, ESTsoft, YD Online, Dragonfly GF Co., SundayToz, Netmarble Games, \\
& LONGTU KOREA Inc., ME2ON Co., Thumbage, Entermate, Golfzon \\
\hline & LF, BYC, SBW Inc., Daehyun Inc., Shinwon Co., Hyungji Elite, Inthef, \\
& NAMYEUNG VIVIEN Co., Cowell Fashion, GNCO, WELCRON, \\
& GOODPEOPLE Co., HYUNGJI I\&C CO., DECO\&E, ACT Co., Coreana \\
& Cosmetics, Able-CNC, Amore Pacific, HANKOOK COSMETICS, Donwon F\&B, \\
& Pulmuone, Ottogi, ORION Holdings Corp, Sempio Foods, CJ CheilJedang, \\
& Nongshim, Samyang, Sajo Haepyo, Namyang Dairy Products Co., Lotte Foods, \\
& CROWNHAITAI Holdings, Binggrae, Maeil Dairies Co., Donsuh Companies Inc., \\
& SPC Samlip, Harim Co., KleanNara, Daesang \\
\hline
\end{tabular}

\subsection{Event Study Methodology}

In order to explore the effect of a celebrity endorsement contract announcement on technologyfocused and marketing-focused firms, the current study uses a market model of domestic stock markets to conduct event study methodology with reference to previous literature (Agrawal and Kamakura 1995). Thus, in the present study, we analyzed the 10-day stock price fluctuation based on each date of contract announcement using the cumulative average abnormal return (CAAR). Analyzing the CAAR, which is the standard practice of an event study, allows us to capture the market's progressive reaction surrounding the contract announcement and to identify the spread effect due to consumers' reaction to the gradual availability of information, and the interpretation of the impact of the celebrity contracts on future firm profitability (Agrawal and Kamakura 1995; Aharony and Swary 1980). Specifically, in the case of calculating the excess returns of each firm that corresponds to the event, the event window for estimating the parameter is set at 239 days ( $t-244$ to $t-6$ days relative to event day, $t=0$ ) in order to estimate the regression coefficients $\alpha_{i}$ and $\beta_{i}$ by ordinary least squares (OLS) in equation (1) for the corresponding time series data.

(1) $R_{i, t}=\alpha_{i}+\beta_{i} \gamma_{m t}+e_{i t}$; Return of a security $i$ at the date $t$ of an event

$\gamma_{m t}$ : Return of composite stock price index at the date $t$

$\alpha_{i}$ : Estimated constant of a security $i$

$\beta_{i}$ : Estimated beta coefficient of a security $i$

$e_{i t}$ : Error term of a security $i$ at the date $t$ 
Using the coefficient estimates of $\widehat{\alpha_{i}}$ and $\hat{\beta}_{i}$, the daily abnormal return (AR) for the event period is calculated as (2).

(2) $A R_{i t}=R_{i t}-\left(\hat{\alpha_{i}}+\hat{\beta}_{i} R_{m t}\right)$

The daily average abnormal return (AAR) is derived by using the average of the abnormal returns of individual stocks obtained from equation (2).

(3) $A A R_{t}=\frac{1}{N} \sum_{j=1}^{N} A R_{i t}$

$N_{t}$ : Number of firms announcing a celebrity endorsement contract at the date $t$

Using the abnormal returns of a security, the sum of AAR represents the cumulative average abnormal return (CAAR) as follows:

(4) $C A A R_{t}=\sum_{t=1}^{T} A A R_{t}$

\subsection{Results}

In Study 3, we first conducted a cross-sectional regression analysis of 37 technology-focused firms and 38 marketing-focused firms in South Korea to identify the determinants of abnormal returns due to the announcement of celebrity endorsement contracts. In the case of 89 events from technology-focused firms and 141 events from marketing-focused firms, we collected each firm's market equity (ME), return on equity (ROE), market cap (BE/ME), debt to equity $(\mathrm{D} / \mathrm{E})$ ratio, and standard deviation of daily returns (STD) for the past five years from the year before the announcement of the relevant company. These variables were treated as control variables. The currency used for the present study is the South Korean won (KRW). Beta is the firm's beta coefficient for the estimated period.

Second, 37 technology-focused firms and 38 marketing-focused firms with records of a celebrity endorsement contract (i.e., events) from January 1, 2014 to December 31, 2016 were assigned event intervals from -10 days to +10 days. To obtain the CAAR, each AR was calculated by measuring the expected return using the beta estimated for the estimation period from -244 days to -6 days based on the contract announcement date. In other words, the announcement date of the celebrity contract was denoted as an event window at 0 , and the periods right before and after the announcement date was presented as -1 day and +1 day, respectively. Then, the CAAR for both types of firms were investigated.

The event study revealed a decreasing movement of the CAAR which indicates that the announcement of a celebrity contract resulted in a negative impact on the technology-focused firms in terms of firms' future profitability (Figure 3). Specifically, for technology-focused firms, the CAAR within the event window (i.e., \pm 10 days) revealed that the effect of the 
〈Figure 3〉 CAAR for \pm 10 Days from Announcement of a Celebrity Endorsement

Contract of Technology-focused Firms

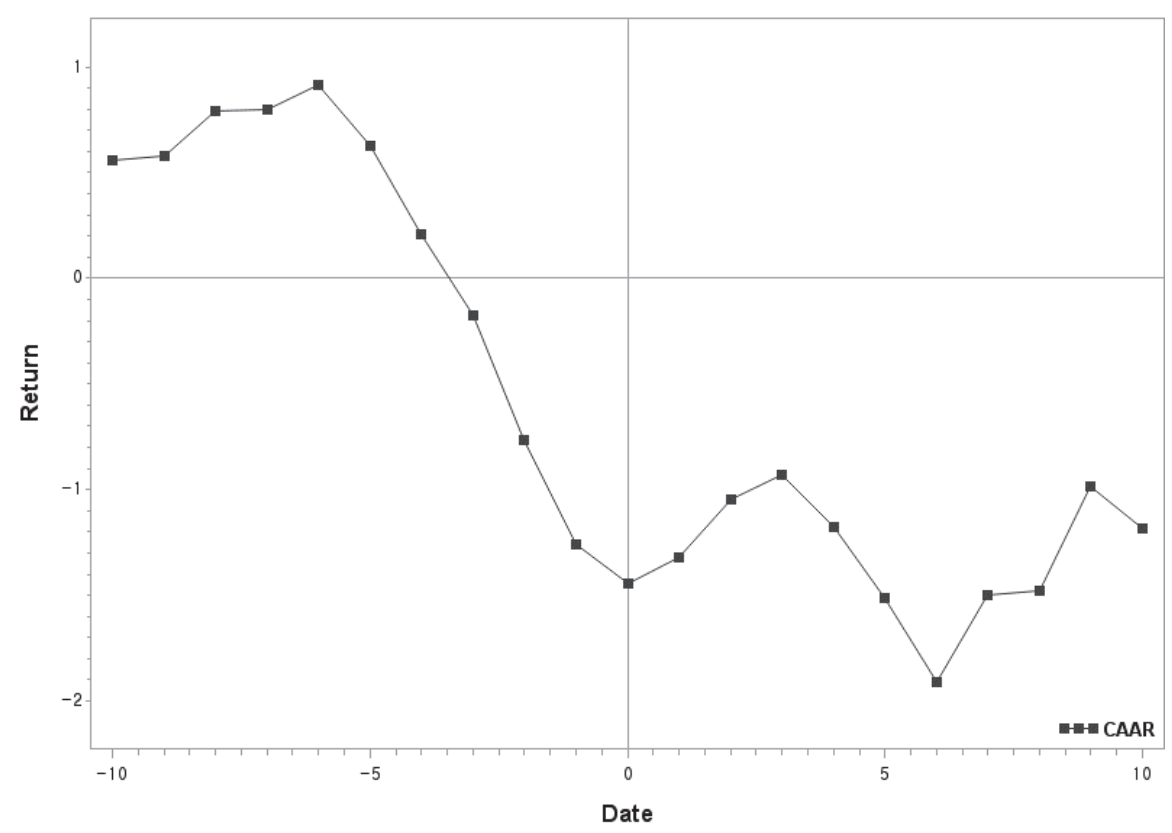

announcement of the celebrity endorsement contract during the event period on the firms' stock return was significantly negative $(M=$ $-.58, t(20)=-2.79, p<.05)$.

Contrary to the movement of the CAAR of the technology-focused firms, an increasing movement of the CAAR of the marketingfocused firms was found (Figure 4). Specifically, the CAAR of each event date of the marketingfocused firms depicted that the celebrity endorsement contract announcement resulted in a significant positive impact on the stock return, which reflects the corporate value of marketing-focused firms during the event period $(M=.63, t(20)=7.972, p<.01)$, and thus supporting our hypotheses. Therefore, the event study provided converging empirical evidence that the effect of a celebrity endorsement on the future profitability of firms in terms of corporate value differs depending on the type of firm.

\subsection{Discussion}

In this study, we found that the celebrity endorsement contract announcement can have a bidirectional influence on the firm's stock return in accordance with the strategic focus of firms. In support of our hypotheses, we found empirical evidence from the stock market that the announcement of a celebrity contract endorsement provided a positive cumulative 
〈Figure 4〉 CAAR for \pm 10 Days from Announcement of a Celebrity Endorsement Contract of Marketing-focused Firms

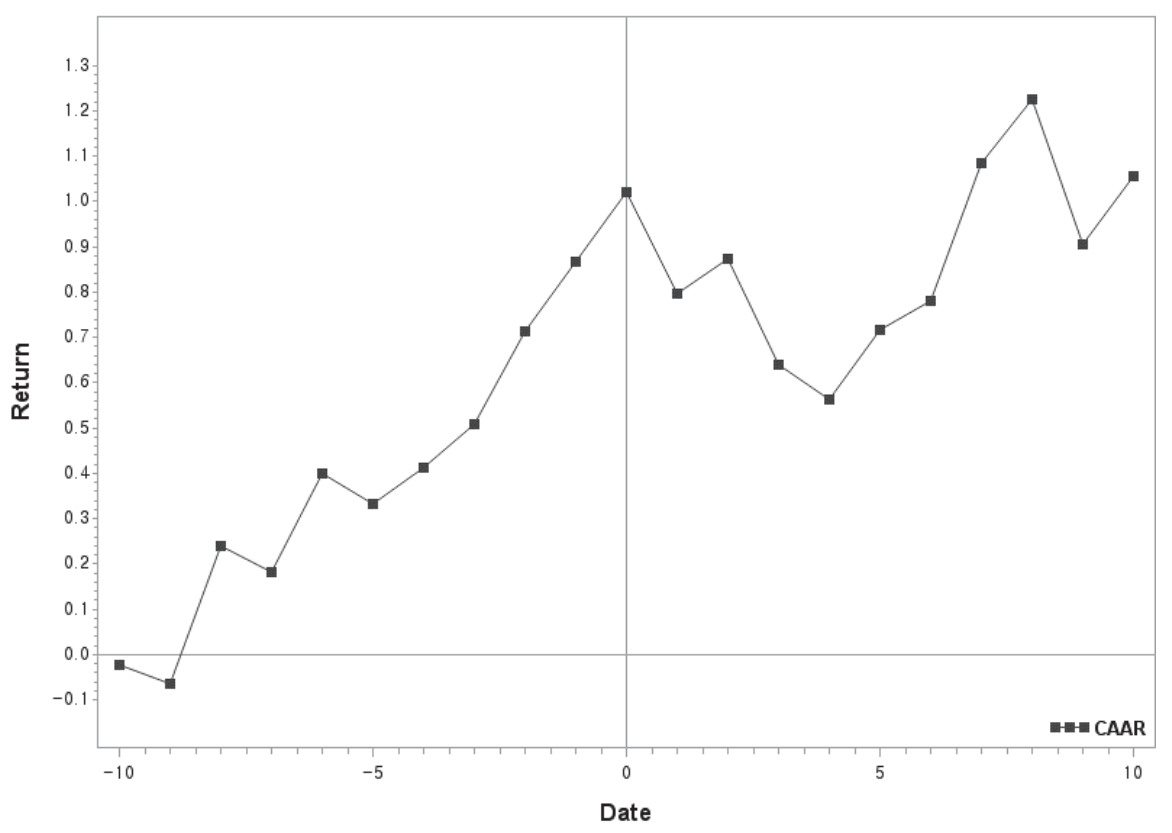

effect toward the marketing-focused firms, but a negative effect on technology-focused firms during the investigated event period.

\section{General Discussion}

The present study examined how a celebrity endorsement contract announcement can be linked to different levels of a brand's growth, which individuals perceive depending on the strategic focus of firms. Earlier work has suggested that individuals generally valued the celebrity endorsement positively. However, throughout the three studies, we consistently found that when consumers categorize a brand as technology-focused, the celebrity endorsement contract negatively affects consumer judgment about a brand's growth in the marketplace. Furthermore, we found a theoretically meaningful mediator, quality inference of a product, of this backfiring effect of a celebrity endorsement contract on consumer judgments about a brand. Unlike Study 1 and Study 2, which employed behavioral experiments, in Study 3, we provided additional evidence for the proposed effect in the real world. Specifically, in Study 3, we conducted the event study based on the actual market reaction and analyzed the cumulative abnormal return (CAAR) from the perspective of the firms with two strategic focuses (i.e., 
technology-focused and marketing-focused) in the stock market resulting from the celebrity contract announcement. As a result, a negative movement was observed from the technologyfocused firms during the event period while a positive cumulative movement of the stock return was found among the marketing-focused firms. These findings suggested that the information on the celebrity endorsement contract may indeed undermine the future profitability of the technology-focused firm.

This research can contribute to the existing literature on the effect of a celebrity endorsement for a brand. Unlike most previous research that focused on the fit between the celebrity and the brand (Lynch and Schuler 1994; Misra and Beatty 1990; Ding, Molchanov and Stork 2011), this research proposed a novel factor that can determine the effectiveness of a celebrity endorsement contract. That is, the strategic focus of a brand. In addition, unlike most research in the domain of advertising effectiveness, this research investigates the effect of celebrity marketing on consumer judgment regarding a brand's growth in the future marketplace. Drawing on consumer inference literature, this research can enrich our understanding of consumer reactions toward a brand's marketing action, such that a celebrity endorsement can serve an inferential cue of a firm's resource allocation and lead to an inferential conclusion that the brand will or will not be promising in the future.
In this respect, the implications of this research are quite straightforward. Much research suggested that a celebrity endorsement can lead to increase brand equity, since it enables the firms to gain rapid recognition from the target customers (Keller 1993). This research identified an important boundary condition of the positive effects of a celebrity endorsement on consumer judgment about a brand. That is, we propose that when a brand is likely categorized as technologyfocused one, blatant investment in marketing such as celebrity endorsement may bring more harm than good for the brand. Consumers may infer that the brand diverts resources away from product advancement in order to perform star marketing. The inference may also tarnish consumers' perceptions of product quality and overall evaluations about a brand regarding its success in the future marketplace. Future research can examine other types of perceived trade-offs that consumers hold in respect to a firm's actions.

〈Received July 24. 2018〉 〈Accepted October 11. 2018〉

\section{References}

Aaker, David A. (1989), "Managing Assets and Skills: The Key to a Sustainable Competitive Advantage," California Management Review, 31 (2), 91-106. 
Agrawal, Jagdish and Wagner A. Kamakura (1995), "The Economic Worth of Celebrity Endorsers: An Event Study Analysis," Journal of Marketing, 59 (3), 56-62.

Aharony, Joseph and Itzhak Swary (1980), "Quarterly Dividend and Earnings Announcements and Stockholders' Returns: An Empirical Analysis," The Journal of Finance, 35 (1), $1-12$.

Babakus, Emin, Carol C. Bienstock, and James R. Van Scotter (2004), "Linking Perceived Quality and Customer Satisfaction to Store Traffic and Revenue Growth," Decision Sciences, 35 (4), 713-37.

Brown, Stephen J. and Jerold B. Warner (1985), "Using Daily Stock Returns: The Case of Event Studies," Journal of Financial Economics, 14 (1), 3-31.

Chernev, Alexander and Gregory S. Carpenter (2001), "The Role of Market Efficiency Intuitions in Consumer Choice: A Case of Compensatory Inferences," Journal of Marketing Research, 38 (3), 349-61.

Ding, Haina, Alexander E. Molchanov, and Philip A. Stork (2011), "The Value of Celebrity Endorsements: A Stock Market Perspective," Marketing Letters, 22 (2), 147-63.

Fama, Eugene F. and Kenneth R. French (1992), "The Cross-Section of Expected Stock Returns," The Journal of Finance, 47 (2), 427-65.

Fama, Eugene F., Lawrence Fisher, Michael
C. Jensen, and Richard Roll (1969), "The Adjustment of Stock Prices to New Information," International Economic Review, 10 (1), 1-21.

Friedman, Hershey H. and Linda Friedman (1979), "Endorser Effectiveness by Product Type," Journal of Advertising Research, 19 (5), 63-71.

Gatignon, Hubert and Jean-Marc Xuereb (1997), "Strategic Orientation of the Firm and New Product Performance," Journal of Marketing Research, 34 (1), 77.

Gershoff, Andrew D. and Judy K. Frels (2015), "What Makes It Green? The Role of Centrality of Green Attributes in Evaluations of the Greenness of Products," Journal of Marketing, 79 (1), 97-110.

Gregan-Paxton, Jennifer, Steve Hoeffler, and Min Zhao (2005), "When Categorization Is Ambiguous: Factors That Facilitate the Use of a Multiple Category Inference Strategy," Journal of Consumer Psychology, 15 (2), 127-40.

Gullov-Singh, Arnie (2011), "The Social Era of Celebrity Endorsements," Retrieved from Adly.com.

Hayes, Andrew F. (2017), Introduction to Mediation, Moderation, and Conditional Process Analysis, Second Edition: A Regression-Based Approach, Guilford Publications.

Heath, Timothy B., Michael S. McCarthy, and David L. Mothersbaugh (1994), "Spokesperson 
Fame and Vividness Effects in the Context of Issue-relevant Thinking: The Moderating Role of Competitive Setting," Journal of Consumer Research, 20 (4), 520-34.

Jacobson, Robert and David A. Aaker (1987), "The Strategic Role of Product Quality," Journal of Marketing, 51 (4), 31-44.

Jain, Shailendra Pratap and Steven S. Posavac (2004), "Valenced Comparisons,” Journal of Marketing Research, 41 (1), 46-58.

Kamins, Michael A., Meribeth J. Brand, Stuart A. Hoeke, and John C. Moe (1989), "Two-Sided versus One-Sided Celebrity Endorsements: The Impact on Advertising Effectiveness and Credibility," Journal of Advertising, 18 (2), 4-10.

Keller, Kevin Lane (1993), “Conceptualizing, Measuring, and Managing Customer-Based Brand Equity," Journal of Marketing, 57 (1), 1-22.

Kirmani, Amna and Peter Wright (1989), “Money Talks: Perceived Advertising Expense and Expected Product Quality," Journal of Consumer Research, 16 (3), 344-53.

Loken, Barbara, Lawrence W. Barsalou, and Christopher Joiner (2008), “Categorization Theory and Research in Consumer Psychology: Category Representation and Categorybased Inference," in Handbook of Consumer Psychology, C. P. Haugtvedt, P. M. Herr, and F. R. Kardes, eds., New York: Psychology Press, 133-63.

Lynch, James and Drue Schuler (1994), “The
Matchup Effect of Spokesperson and Product Congruency: A Schema Theory Interpretation," Psychology \& Marketing, 11 (5), 417-45. McCracken, Grant (1989), "Who is the Celebrity Endorser? Cultural Foundations of the Endorsement Process," Journal of Consumer Research, 16 (3), 310-21.

Misra, Shekhar and Sharon E. Beatty (1990), "Celebrity Spokesperson and Brand Congruence," Journal of Business Research, 21 (2), 15973.

Mowen, John C. and Stephen W. Brown (1981), "On Explaining and Predicting the Effectiveness of Celebrity Endorsers," ACR North American Advances, NA-08. Newman, George E., Margarita Gorlin, and Ravi Dhar (2014), "When Going Green Backfires: How Firm Intentions Shape the Evaluation of Socially Beneficial Product Enhancements," Journal of Consumer Research, 41 (3), 823-39.

Oh, Choonho, Yongrae Cho, and Wonjoon Kim (2015), “The Effect of a Firm's Strategic Innovation Decisions on Its Market Performance," Technology Analysis \& Strategic Management, 27 (1), 39-53.

Paek, Hye-Jin (2005), “Understanding Celebrity Endorsers in Cross-cultural Contexts: A Content Analysis of South Korean and US Newspaper Advertising," Asian Journal of Communication, 15 (2), 133-53.

Park, C. Whan, Bernard J. Jaworski, and Deborah J. Maclnnis (1986), "Strategic Brand Concept- 
Image Management," Journal of Marketing, 50 (4), 135.

Posavac, Steven S., Michal Herzenstein, Frank

R. Kardes, and Suresh Sundaram (2010), "Profits and Halos: The Role of Firm Profitability Information in Consumer Inference," Journal of Consumer Psychology, 20 (3), 327-37.

Preacher, Kristopher J. and Andrew F. Hayes (2008), "Asymptotic and Resampling Strategies for Assessing and Comparing Indirect Effects in Multiple Mediator Models," Behavior Research Methods, 40 (3), 879-91.

Rindova, Violina P., Timothy G. Pollock, and Mathew L. A. Hayward (2006), "Celebrity Firms: The Social Construction of Market Popularity," Academy of Management Review, 31 (1), 50-71.

Rosch, Eleanor (1978), "Principles of Categorization," in Cognition and Categorization, Eleanor
Rosch and Barbara B. Lloyd, eds. Hillsdale, New Jersey: Lawrence Elbaum, 27-48. Schwarz, Norbert (2004), "Metacognitive Experiences in Consumer Judgment and Decision Making," Journal of Consumer Psychology, 14 (4), 332-48.

Voss, Kevin E., Eric R. Spangenberg, and Bianca Grohmann (2003), "Measuring the Hedonic and Utilitarian Dimensions of Consumer Attitude," Journal of Marketing Research, 40 (3), 310-20.

Weigelt, Keith and Colin Camerer (1988), "Reputation and Corporate Strategy: A Review of Recent Theory and Applications," Strategic Management Journal, 9 (5), $443-54$.

Zhou, Kevin Zheng, Chi Kin (Bennett) Yim, and David K. Tse (2005), "The Effects of Strategic Orientations on Technology- and Market-Based Breakthrough Innovations," Journal of Marketing, 69 (2), 42-60. 